\title{
クロムアズロール S の酸解離定数に及ぼすゼフィラミン 及び塩化物イオンの影響
}

\author{
西田宏* \\ (1988 年 11 月 28 日受理)
}

\begin{abstract}
水溶液中で, ゼフィラミン存在下クロムアズロール $\mathrm{S}\left(\mathrm{CAS}, \mathrm{H}_{4} \mathrm{~L}\right)$ の見掛けの第三段酸解離定数 $\left(K_{\mathrm{a} 3}^{\prime}\right)$ は，塩化物イオン濃度の増大と共に減少した。これは $\mathrm{H}_{2} \mathrm{~L}^{2-}$ 及び $\mathrm{HL}^{3-}$ の水相とミセル相の間の分配 比 $\left(D_{\mathrm{H} 2 \mathrm{II}}\right.$ 及び $\left.D_{\mathrm{HL}}\right)$ が，それぞれ [塩化物イオン] ${ }^{2}$ 及び [塩化物イオン]にほぼ比例して増大するた めであった. 従って, この反応機構は, 水相中の CAS とミセル相中の塩化物イオンのイオン交換反応 モデルによって説明できなかった。水相で生成したゼフィラミン，CAS 及び塩化物イオンから成る疎 水性の大きい化合物が，ミセル相の内部に取り込まれて可溶化されると考えられる. 又, ゼフィラミン 存在下 $\mathrm{pH} 10.2$ で, ベリリウム-CAS 錯体のミセル相への分配に及ぼす塩化物イオンの影響, 及び CAS によるベリリウムの吸光光度定量に及ぼす塩化物イオンの影響についても検討を行った.
\end{abstract}

\section{1 緒言}

既報1)では，塩化物イオンなよ゙陰イオンの濃度の増大 と共に，ゼフィラミン (ZCl で示す) 存在下でのクロム アズロール S (以下 CAS と略記， $\mathrm{H}_{4} \mathrm{~L}$ で示す) の水相 とミセル相間の分配比 $\left(\mathrm{H}_{2} \mathrm{~L}^{2-}\right.$ 及び $\mathrm{HL}^{3-}$ の分配比を それぞれ $D_{\mathrm{H} 2 \mathrm{~L}}$ 及び $D_{\mathrm{H} 1}$ ，とする）が増大し，その結果 CAS の見掛けの第三段の酸解離定数 $K_{\mathrm{a} 3}^{\prime}$ が減少するこ とを示した. しかし，その反応機構は明らかでない。そ れは, 次の理由による. ゼフィラミンのようなイオン性 界面活性剂水溶液において, CAS のような水溶性イオ ン化合物は, ミセル表面近傍の対イオンとのイオン交換 反応によって2(2)15), ミセル相に取り込まれ，主にミセ ル表面の親水基付近に吸着して可溶化され平衡に達する と考えられてきた2)-7). しかし，この反応モデルによ ると, 陰イオン濃度の増大と共に分配比が減少すること になり ${ }^{2)}, K_{\mathrm{a} 3}^{\prime}$ に対するゼフィラミン及び塩化物イオン などの作用を説明することができない，そこで， $K_{\mathrm{a} 3}^{\prime}$ に 対するゼフィラミン及び塩化物イオンの影響について更 に詳細に検討し, 既報")の結果と比較し, その新しい反 応機構モデルを提案した. 又, 得られた分配比の值を用 いて，ゼフィラミン存在下 $\mathrm{pH} 10$ での CAS によるベリ リウムの吸光光度定量 ${ }^{8)}$ における反応機構についても考 察を行った。

* 岩手大学工学部共通講座 : 020 岩手県盛岡市上田 4-3-5

\section{2 実験}

\section{$2 \cdot 1$ 試薬及び装置}

CAS 溶液 $\left(0.125 \mathrm{mg} \mathrm{cm}^{-3}, 0.250 \mathrm{mg} \mathrm{cm}^{-3}\right)$, ゼフィ ラミン溶液 $\left(10 \mathrm{mg} \mathrm{cm}^{-3}\right)$, ベリリウム標準溶液 $(\mathrm{Be}$ $\left.1.00 \mu \mathrm{g} \mathrm{cm}^{-3}\right)$ 及び緩衝溶液は既報 ${ }^{1) 8)}$ と同様にして調 製した。その他の試薬はすべて特級品を用いた。

吸光度, $\mathrm{pH}$ の測定には既報 ${ }^{1)}$ と同様のものを用い た。

実験は $25 \pm 0.5^{\circ} \mathrm{C}$ で行った.

\section{$2 \cdot 2$ 実験操作}

既報1)と同様にして行った.

\section{3 結果及び考察}

\section{$3 \cdot 1 \quad K_{\mathrm{a} 3}^{\prime}$ に及ぼす塩化物イオンの影響}

$K_{\mathrm{a} 3}^{\prime}$ と $0.05 \sim 1.28 \mathrm{~mol} \mathrm{dm}^{-3}$ 塩化物イオン及びゼフィ ラミン濃度との関係を調べた結果を Fig. 1 に示す。こ れから既報 ${ }^{1)}$ と同様の方法で $D_{\mathrm{H} 2 \mathrm{~L}}$ 及び $D_{\mathrm{HL}}$ を求め, これらの值の対数と塩化物イオン濃度の対数との関係を Fig. 2 に示す.なお, Fig. 2 には, 既報”で得られた 塩化物イオン及び硫酸イオンの結果も併せて示す。これ らの間にはほぼ直線関係が成立し，そのこう配はそれぞ れ 1.98 及び 0.95 であった（硫酸イオンの場合, こう配 はそれぞれ 0.95 及び 0.53 であった)，こう配の値が正 確に整数值を示さないのは, 関与するイオン種の活量係 


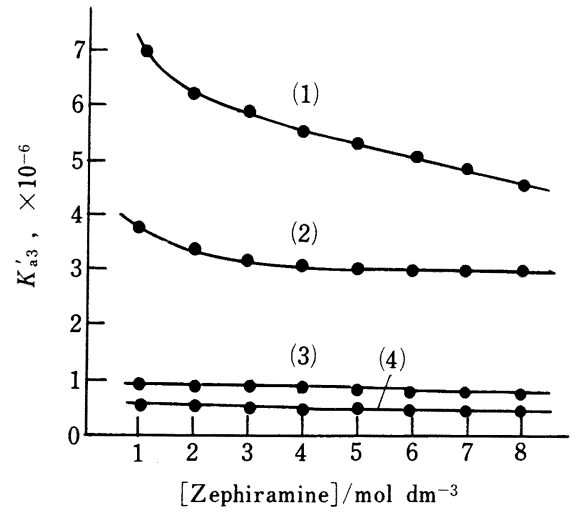

Fig. 1 Relation between $K_{\mathrm{a} 3}^{\prime}$ and Zephiramine concentration

$\left[\mathrm{Cl}^{-}\right]\left(\mathrm{mol} \mathrm{dm}{ }^{-3}\right):$ (1) 0.05 , (2) 0.16 , (3) 0.64 , (4) 1.28

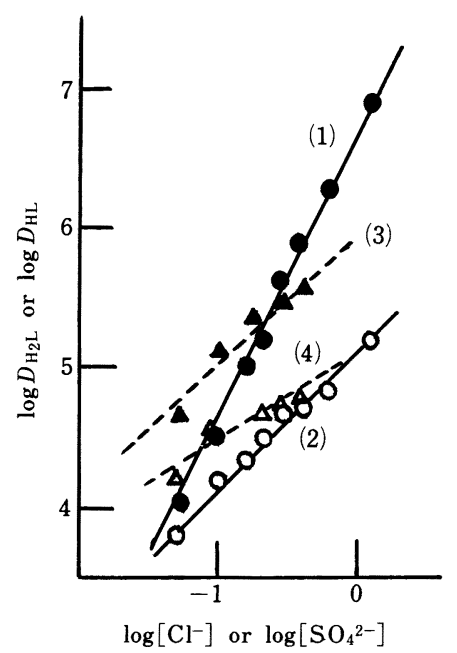

Fig. 2 Relation between $\log D_{\mathrm{H} 2 \mathrm{~L}}$ or $\log D_{\mathrm{HL}}$ and logarithm of anion concentration

$D_{\mathrm{H} 2 \mathrm{~L}}:(1)(3) ; D_{\mathrm{HL}}:(2)(4) ; \bigcirc:$ chloride ; $\triangle$ : sulfate

数の変化によるものと考えられる.

従来考えられたように, $\mathrm{H}_{2} \mathrm{~L}^{2-}$ 及び $\mathrm{HL}^{3-}$ がミセル 相中の対イオンとのイオン交換反応によって ${ }^{2)}$, ミセル 表面に吸着され可溶化されるとすると，その反応は式 ( 1 )及び式( 2 )で与えられることになる.

$$
\begin{aligned}
& {\left[\mathrm{H}_{2} \mathrm{~L}^{2-}\right]_{\mathrm{w}}+2\left[\mathrm{Cl}^{-}\right]_{\mathrm{s}} \rightleftarrows\left[\mathrm{H}_{2} \mathrm{~L}^{2-}\right]_{\mathrm{s}}+2\left[\mathrm{Cl}^{-}\right]_{\mathrm{w}}} \\
& {\left[\mathrm{HL}^{3-}\right]_{\mathrm{w}}+3\left[\mathrm{Cl}^{-}\right]_{\mathrm{s}} \rightleftarrows\left[\mathrm{HL}^{3-}\right]_{\mathrm{s}}+3\left[\mathrm{Cl}^{-}\right]_{\mathrm{w}}}
\end{aligned}
$$

ここで, 添字 $\mathrm{w}, \mathrm{s}$ はそれぞれ水相及びミセル相を示 す. 式（1）及び（2）の反応の平衝定数をそれぞれ $k_{\mathrm{H} 2 \mathrm{~L} / \mathrm{Cl}}$ 及び $k_{\mathrm{HL} / \mathrm{C} 1}$ とすれば, $D_{\mathrm{H} 2 \mathrm{~L}}=k_{\mathrm{H} 2 \mathrm{~L} / \mathrm{Cl}}\left[\mathrm{Cl}^{-}\right]_{\mathrm{s}}^{2} /$ $\left[\mathrm{Cl}^{-}\right]_{\mathrm{w}}^{2}$ 及び $D_{\mathrm{HL}}=k_{\mathrm{HL} / \mathrm{Cl}}\left[\mathrm{Cl}^{-}\right]_{\mathrm{s}}^{3} /\left[\mathrm{Cl}^{-}\right]_{\mathrm{w}}^{3}$ を得る. $\left[\mathrm{Cl}^{-}\right]_{\mathrm{s}}$ の值はほぼ一定としてよいので2)， $D_{\mathrm{H} 2 \mathrm{~L}}$ 及び $D_{\mathrm{HL}}$ は $\left[\mathrm{Cl}^{-}\right]_{\mathrm{w}}$ の增大と共に娍少することになり，Fig. 2 の結 果を説明することができない.

基質 $\mathrm{M}$ のミセル相及び水相中の見掛けの濃度をそれ ぞれ $\left[\mathrm{M}_{\mathrm{s}}\right]$ 及び $\left[\mathrm{M}_{\mathrm{w}}\right]$ とし, $[\mathrm{C}]=($ 界面活性剂濃度一 臨界ミセル濃度)， $K_{\mathrm{M}}$ を $\mathrm{M}$ の結合定数とすると, $K_{\mathrm{M}}$ $=\left[\mathrm{M}_{\mathrm{s}}\right] /\left[\mathrm{M}_{\mathrm{w}}\right]\left([\mathrm{C}]-\left[\mathrm{M}_{\mathrm{w}}\right]\right)$ で与えられる ${ }^{2) 4) 5)} \cdot \mathrm{M} の$ 分配比を $D_{\mathrm{M}}, V_{\mathrm{s}}, V_{\mathrm{w}}$ をそれぞれミセル相及び水相の 容積分率 $\left(V_{\mathrm{w}} \gg V_{\mathrm{s}}, V_{\mathrm{w}} \doteqdot 1\right.$ とする $), \phi$ を界面活性剤のモ ル容積とすると, $D_{\mathrm{M}}$ と $K_{\mathrm{M}}$ の間には, $D_{\mathrm{M}}=\left[\mathrm{M}_{\mathrm{s}}\right] V_{\mathrm{w}} /$ $\left[\mathrm{M}_{\mathrm{w}}\right] V_{\mathrm{s}}=\left[\mathrm{M}_{\mathrm{s}}\right] /\left[\mathrm{M}_{\mathrm{w}}\right] \phi\left([\mathrm{C}]-\left[\mathrm{M}_{\mathrm{w}}\right]\right)=K_{\mathrm{M}} / \phi$ の関係が 成立する.ここで $\phi$ は界面活性剤の長鎖アルキル基の モル容積にほぼ等しい ${ }^{16)}$. ゼフィラミンでは $\phi=0.243$ $\mathrm{dm}^{3} \mathrm{~mol}^{-1}$ となる. 分子量の大きい芳香族アミン $\mathrm{A}$ と 陽イオン界面活性剤では $K_{\mathrm{M}}$ は $10^{4}$ 台であるが, $\mathrm{AH}^{+}$ と陰イオン界面活性剤では $10^{2}$ 台であり ${ }^{4)}$, 又, 他の芳 香族化合物も同様の傾向を示す ${ }^{910)}$.これは, 疎水性分 子と陽イオン界面活性剂との分子間の結合力が大きいこ とを示す ${ }^{4)}$. CAS も分子量が比較的大きく, 疎水的であ ることから, 分子間結合力と静電的結合力の相乗効果に よって, 水相においてゼフィラミンと強く結合して更に 疎水性を増大し, 塩化物イオンと共に, 容易にミセルに 可溶化されると考えられる.

そこで, Fig. 1 及び Fig. 2 の関係を説明するため, 次のような新しい反応機構を考えた. $\left[\mathrm{H}_{2} \mathrm{~L}^{2-}\right]_{\mathrm{w}}$ 及び $\left[\mathrm{HL}^{3-}\right]_{\mathrm{w}}$ が, 水相中のゼフィラミン $\left[\mathrm{Z}^{+}\right]_{\mathrm{w}}$ 及び $\left[\mathrm{Cl}^{-}\right]_{\mathrm{w}}$ と反応し，ミセルに可溶化されるとすると, Fig. 2 の結 果から, 反応はそれぞれ式 $(3)$ 及び式 $(4)$ で与えられ る.

$$
\begin{aligned}
{\left[\mathrm{H}_{2} \mathrm{~L}^{2-}\right]_{\mathrm{w}}+4\left[\mathrm{Z}^{+}\right]_{\mathrm{w}} } & +2\left[\mathrm{Cl}^{-}\right]_{\mathrm{w}} \\
& \stackrel{\rightleftarrows}{\rightleftarrows}\left[\left(\mathrm{Z}_{2} \mathrm{H}_{2} \mathrm{~L}\right)(\mathrm{ZCl})_{2}\right]_{\mathrm{s}} \\
{\left[\mathrm{HL}^{3-}\right]_{\mathrm{w}}+4\left[\mathrm{Z}^{+}\right]_{\mathrm{w}}+\left[\mathrm{Cl}^{-}\right]_{\mathrm{w}} } & \stackrel{\mathrm{Z}}{\rightleftarrows}\left[\left(\mathrm{Z}_{3} \mathrm{HL}\right)(\mathrm{ZCl})\right]
\end{aligned}
$$

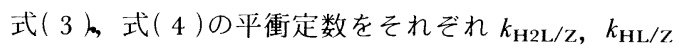
とし,これらの值が大きいので $\left[\mathrm{H}_{2} \mathrm{~L}^{2-}\right]_{\mathrm{w}}$ 及び $\left[\mathrm{HL}^{3-}\right]_{\mathrm{w}}$ が小さく, $\left[\mathrm{Z}^{+}\right]_{\mathrm{w}} \gg\left[\mathrm{H}_{2} \mathrm{~L}^{2-}\right]_{\mathrm{w}},\left[\mathrm{Z}^{+}\right]_{\mathrm{w}} \gg\left[\mathrm{HL}^{3-}\right]_{\mathrm{w}}$ とす ると, $\left[Z^{+}\right]_{w}$ は臨界ミセル濃度にほぼ等しく, 塩化物 イオン濃度が一定のとき，ほぼ一定とみなしてよい。 又, 式( 1$)$, 式( 2 )による $\left[\mathrm{H}_{2} \mathrm{~L}^{2-}\right]_{\mathrm{s}}$ 及び $\left[\mathrm{HL}^{3-}\right]_{\mathrm{s}}$ も 極めて小さいとすると, $D_{\mathrm{H} 2 \mathrm{~L}}$ 及び $D_{\mathrm{HI}}$ はそれぞれ式 
( 5 )及び式( 6 )で与えられる.

$$
\begin{aligned}
& D_{\mathrm{H} 2 \mathrm{~L}} \doteqdot\left[\left(\mathrm{Z}_{2} \mathrm{H}_{2} \mathrm{~L}\right)(\mathrm{ZCl})_{2}\right]_{\mathrm{s}} /\left[\mathrm{H}_{2} \mathrm{~L}^{2-}\right]_{\mathrm{w}} \\
& \fallingdotseq k_{\mathrm{H} 2 \mathrm{~L} / \mathrm{Z}}\left[\mathrm{Z}^{+}\right]_{\mathrm{w}}^{4}\left[\mathrm{Cl}^{-}\right]_{\mathrm{w}}^{2} \\
& D_{\mathrm{HL}} \doteqdot\left[\left(\mathrm{Z}_{3} \mathrm{HL}\right)(\mathrm{ZCl})\right]_{\mathrm{s}} /\left[\mathrm{HL}^{3-}\right]_{\mathrm{w}} \\
& \doteqdot k_{\mathrm{HL} / \mathrm{Z}}\left[\mathrm{Z}^{+}\right]_{\mathrm{w}}^{4}\left[\mathrm{Cl}^{-}\right]_{\mathrm{w}}
\end{aligned}
$$

式( 3 )〜式( 6 )から， $K_{\mathrm{a} 3}^{\prime}$ は式( 7 )で与えられる1).

$$
\begin{gathered}
K_{\mathrm{a} 3}^{\prime} \div \frac{\left(\left[\mathrm{HL}^{3-}\right]_{\mathrm{w}} V_{\mathrm{w}}+\left[\left(\mathrm{Z}_{3} \mathrm{HL}\right)(\mathrm{ZCl})\right]_{\mathrm{s}} V_{\mathrm{s}}\right)\left[\mathrm{H}^{+}\right]_{\mathrm{w}} V_{\mathrm{w}}}{\left(\left[\mathrm{H}_{2} \mathrm{~L}^{2-}\right]_{\mathrm{w}} V_{\mathrm{w}}+\left[\left(\mathrm{Z}_{2} \mathrm{H}_{2} \mathrm{~L}\right)(\mathrm{ZCl})_{2}\right]_{\mathrm{s}} V_{\mathrm{s}}\right)} \\
=\frac{K_{\mathrm{a} 3}^{\prime}\left(1+k_{\mathrm{HL} / \mathrm{Z}}\left[\mathrm{Z}^{+}\right]_{\mathrm{w}}^{4}\left[\mathrm{Cl}^{-}\right]_{\mathrm{w}} V_{\mathrm{s}}\right)}{\left(1+k_{\mathrm{H} 2 \mathrm{~L} / \mathrm{Z}}\left[\mathrm{Z}^{+}\right]_{\mathrm{w}}^{4}\left[\mathrm{Cl}^{-}\right]_{\mathrm{w}}^{2} V_{\mathrm{s}}\right)}
\end{gathered}
$$

ここで, $V_{\mathrm{w}}$ 及び $V_{\mathrm{s}}$ はそれぞれ水相及びミセル相の 容積分率で, $V_{\mathrm{w}} \gg V_{\mathrm{s}}, V_{\mathrm{w}} \doteqdot 1$ とした. $K_{\mathrm{a} 3}^{\prime}=\left[\mathrm{HL}^{3-}\right]_{\mathrm{w}}$ $\left[\mathrm{H}^{+}\right]_{\mathrm{w}} /\left[\mathrm{H}_{2} \mathrm{~L}^{2-}\right]_{\mathrm{w}}$ (水相における CAS の第三段の酸解 離定数）とした. 式( 7 )により， $K_{\mathrm{a} 3}^{\prime}$ に対する塩化物 オン濃度及びゼフィラミン濃度の影響を表すことができ ると考えられる。

\section{3 •2 Be-CAS 錯体の生成に及ぼす塩化物イオンの影} 響

ゼフィラミン存在下 $\mathrm{pH} 10.20$ で生成する Be-CAS $(1: 2)$ 錯体 ${ }^{1)}$ の水相とミセル相の間の分配比 $D_{\mathrm{c}}$ に及ぼ す塩化物イオンの影響を調へ，ミセル相に生成する化合 物の推定を試みた。ミセル相における錯体の生成定数 $k$ は, 式( 8 )で与えられると考えられる1).

$$
k=\frac{\left[\mathrm{Be}(\mathrm{OH})(\mathrm{HL})_{2}{ }^{5-}\right]_{\mathrm{s}}}{\left[\mathrm{Be}^{2+}\right]_{\mathrm{w}}\left[\mathrm{HL}^{3-}\right]_{\mathrm{s}}^{2}}=\frac{K_{1} K_{2} D_{\mathrm{c}}}{D_{\mathrm{HL}}^{2}}
$$

ここで, $K_{\mathrm{l}}=\left[\mathrm{Be}(\mathrm{OH})_{2}(\mathrm{HL})^{3-}\right]_{\mathrm{w}} /\left[\mathrm{Be}^{2+}\right]_{\mathrm{w}}\left[\mathrm{HL}^{3-}\right]_{\mathrm{w}}$ 及び $K_{2}=\left[\mathrm{Be}(\mathrm{OH})(\mathrm{HL})_{2}{ }^{5-}\right]_{\mathrm{w}} /\left[\mathrm{Be}(\mathrm{OH})_{2}(\mathrm{HL})^{3-}\right]_{\mathrm{w}}$ $\left[\mathrm{HL}^{3-}\right]_{\mathrm{w}}$ とし, それぞれ水相における $(1: 1)$ 錯体及び (1:2) 錯体の $\mathrm{pH} 10.20$ における見掛けの逐次生成定数 とする，そこで，まず $K_{1} K_{2}$ に及ぼす塩化物イオンの影 響について検討を行った. Be (II) $1.33 \times 10^{-5} \mathrm{~mol} \mathrm{dm}^{-3}$, $\left[\mathrm{Cl}^{-}\right]_{\mathrm{w}} 0.10 \mathrm{~mol} \mathrm{dm}^{-3}, \mathrm{pH} 10.20$ とし, [CAS] を (0.02 1.2) $\times 10^{-3} \mathrm{~mol} \mathrm{dm}^{-3}$ としたときの錯体の吸収 曲線を Fig. $3(\mathrm{a})$ に示す. [CAS] が $4 \times 10^{-4} \mathrm{~mol} \mathrm{dm}^{-3}$ 以下では, 錯体の吸収極大は $500 \mathrm{~mm}$ 付近にあり, 主 に $1: 1$ 錯体を生成すると考えられる11). [CAS]が $8 \times$ $10^{-4} \mathrm{~mol} \mathrm{dm}^{-3}$ 以上では, その濃度の増大と共に錯体 の吸収極大が $500 \mathrm{~nm}$ から $505 \mathrm{~nm}$ 付近に移行した。 [CAS] が $4 \times 10^{-4} \mathrm{~mol} \mathrm{dm}^{-3}$ 以下では吸光光度法 ${ }^{12)}$ で $K_{1}$ を, $8 \times 10^{-4} \mathrm{~mol} \mathrm{dm}^{-3}$ 以上では平衡濃度法 ${ }^{13)}$ で Fig. 3(a) 及びその他の結果から $K_{1} K_{2}$ を求め, $K_{1} K_{2}$ と

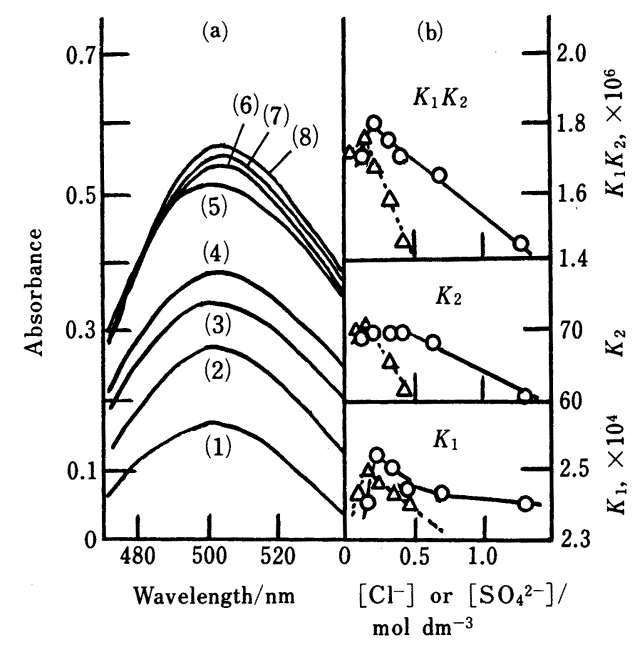

Fig. 3 (a) Absorption spectra of beryllium-CAS complexes in the absence of Zephiramine, and (b) relation between $K_{1}, K_{2}$ or $K_{1} K_{2}$ and anion concentration

(a) $[\mathrm{Be}(\mathrm{II})]: 1.33 \times 10^{-5} \mathrm{~mol} \mathrm{dm}^{-3} ; \quad[\mathrm{CAS}](1 \times$ $\left.10^{-4} \mathrm{~mol} \mathrm{dm}^{-3}\right)$ : (1) 0.201 , (2) $0.402, \quad$ (3) 0.603 , (4) 0.804, (5) 4.02, (6) 8.04, (7) 12.1, (8) 16.1 ; [EDTA] : $4 \times 10^{-4} \mathrm{~mol} \mathrm{dm}{ }^{-3} ;\left[\mathrm{Cl}^{-}\right]: 0.10 \mathrm{~mol}$ $\mathrm{dm}^{-3} ; \mathrm{pH}: 10.20$; Reference : reagent blank. (b) $\bigcirc$ chloride, $\triangle$ sulfate ; $K_{1} K_{2}$ : overall formation constant of $1: 2$ complex at $\mathrm{pH} 10.2$

塩化物イオン濃度の関係を調べ Fig. 3(b)に示す. 比較 のため, $K_{1} K_{2}$ と硫酸イオン濃度の関係も Fig. 3(b) に 示す.この場合, $1: 1$ 錯体は $\mathrm{Be}(\mathrm{OH})_{x}(\mathrm{HL})_{y}{ }^{11)}, 1: 2$ 錯体は, $\left.\mathrm{Be}(\mathrm{OH})(\mathrm{HL})_{2}{ }^{5-1}\right)$ で示され, $\mathrm{Be}(\mathrm{OH})_{3}{ }^{-}$と CAS のカルボキシル基との間のエステル化によって生 成したと考えられる. CAS と同様の官能基をもつサリ チル酸の銅 $(\mathrm{II})$ 及び覀鉛 $(\mathrm{II})$ 錯体では，キレートではな くエステル型錯体が知られている ${ }^{14)}$ ので，この推定が 支持される.

Fig. 2 と Fig. 3(b)の結果及び既報1) で得られた $k$ の 值から式( 8 )によって $D_{\mathrm{c}}$ を求め, $D_{\mathrm{c}}$ の対数と塩化物 イオン濃度の対数との関係を Fig. 4 に示す. 比較のた め, $D_{\mathrm{c}}$ の対数と硫酸イオン濃度の対数との関係も併せ て Fig. 4 に示す.これらの間には直線関係が成立し, そのこう配は 1.98 (硫酸イオンの場合は 0.97 )であっ た. 従って, ゼフィラミン存在下, $\operatorname{Be}-\operatorname{CAS}(1: 2)$ 錯体 は式( 3 )及び式( 4 ) と同様の推定によって, 式( 9 )によ って生成すると考えられる。

$$
\begin{gathered}
{\left[\mathrm{Be}(\mathrm{OH})_{3}{ }^{-}\right]_{\mathrm{w}}+2\left[\mathrm{HL}^{3-}\right]_{\mathrm{w}}+7\left[\mathrm{Z}^{+}\right]_{\mathrm{w}}+2\left[\mathrm{Cl}^{-}\right]_{\mathrm{w}}} \\
\stackrel{\rightleftarrows}{\rightleftarrows}\left[\mathrm{Z}_{5} \cdot \mathrm{Be}(\mathrm{OH})(\mathrm{HL})_{2} \cdot(\mathrm{ZCl})_{2}\right]_{\mathrm{s}}+2 \mathrm{OH}^{-}
\end{gathered}
$$




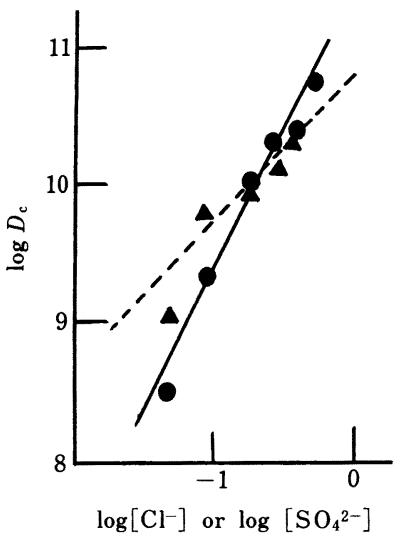

Fig. 4 Relation between $\log D_{\mathrm{c}}$ and logarithm of anion concentration

: chloride; $\boldsymbol{\Delta}$ : sulfate

Fig. 3 及び Fig. 4 に見られるように, $\operatorname{Be}-\operatorname{CAS}(1: 2)$ 錯体の生成は, ゼフィラミン不在下では大過剩の CAS の存在を必要とするが, ゼフィラミン存在下では, $D_{\mathrm{c}}$ が大きいため, 式( 9 )の反応の右への進行が容易になる と考えられる.

\section{$3 \cdot 3$ ベリリウムの吸光光度定量に及ぼす塩化物イオ ンの影響}

比較のため種々の陰イオン存在下でのゼフィラミンー CAS 溶液の $\mathrm{pH} 3.5\left(\mathrm{H}_{2} \mathrm{~L}^{2-}\right.$ として存在 $)$ 及び $\mathrm{pH} 8.5$ ( $\mathrm{HL}^{3-}$ として存在)の吸収曲線を Fig. 5(a)に示す. $\mathrm{pH}$ 3.5 では, 吸光度は $\mathrm{NO}_{3}{ }^{-}>\mathrm{Cl}^{-}>\mathrm{F}^{-}>\mathrm{SO}_{4}{ }^{2-}$ の順であ り, pH 8.5 では吸光度の差は少なかったが同様の傾向 を示した．陽イオン界面活性剤に対する対イオンの相対 結合力は, $\mathrm{NO}_{3}{ }^{-}>\mathrm{Cl}^{-}>\mathrm{SO}_{4}{ }^{2-}$ の順であり ${ }^{15)}$, 又, 陰 イオンが反応に関与すると考えられる $D_{\mathrm{H} 2 \mathrm{~L}}$ の值は, Fig. 2 と同様にして測定したところ, $0.05 \mathrm{~mol} \mathrm{dm}^{-3}$ $\mathrm{NO}_{3}{ }^{-}: 3 \times 10^{4}, \quad 0.05 \mathrm{~mol} \mathrm{dm}{ }^{-3} \mathrm{Cl}^{-}: 1.05 \times 10^{4}, \quad 0.40$ $\mathrm{mol} \mathrm{dm}{ }^{-3} \mathrm{Cl}: 7.1 \times 10^{5}, 0.40 \mathrm{~mol} \mathrm{dm}{ }^{-3} \mathrm{~F}^{-}: 3.2 \times 10^{5}$, $0.40 \mathrm{~mol} \mathrm{dm}^{-3} \mathrm{SO}_{4}{ }^{2-}: 3.85 \times 10^{5}$ であり，ミセルとの 結合力の大きい陰イオンほど，ゼフィラミン-CAS 溶液 の吸光度が大きかった。 又, $\mathrm{pH} 3.5$ と 8.5 のゼフィラ ミン-CAS 溶液の吸光度に及ぼす塭化物イオン及び硫酸 イオン濃度の影響をFig. 5(b) に示し, pH 10.20 における ゼフィラミン存在下での CAS によるベリリウムの吸光 光度定量 ${ }^{8)}$ における試料液とから試験液の $520 \mathrm{~nm}$ にお ける吸光度に及ぼす塩化物イオン及び硫酸イオンの濃度 の影響を Fig. 5(c)に示す。これら陰イオン濃度の増大

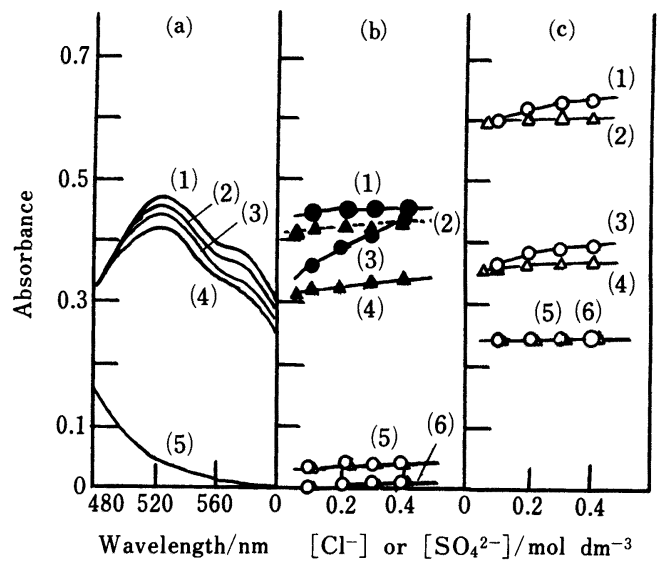

Fig. 5 Effect of anion concentration on the absorbance of CAS solution and on berylliumCAS complex in the presence of Zephiramine

(a) [CAS] : $2.0 \times 10^{-5} \mathrm{~mol} \mathrm{dm}^{-3} ;$ [Zephiramine] $5.9 \times 10^{-3} \mathrm{~mol} \mathrm{dm}^{-3} ; \mathrm{pH}:(1) \sim(4) 3.5$, (5) 8.5 ; $\left[\right.$ Anion] $\left(\mathrm{mol} \mathrm{dm}^{-3}\right):$ (1) $\left[\mathrm{NO}_{3}{ }^{-}\right]$0.05, (2) $\left[\mathrm{Cl}^{-}\right]$ $0.05,(3)\left[\mathrm{F}^{-}\right] 0.40,(4)\left[\mathrm{SO}_{4}{ }^{2-}\right] 0.40,(5)\left[\mathrm{Cl}^{-}\right]$or $\left[\mathrm{SO}_{4}{ }^{2-}\right] 0.40$; Reference : water. (b) [CAS] $: 2.0 \times$ $10^{-5} \mathrm{~mol} \mathrm{dm}{ }^{-3}$; [Zephiramine] : $5.9 \times 10^{-3} \mathrm{~mol}$ $\mathrm{dm}^{-3} ; \mathrm{pH}:(1) \sim(4) 3.5$, (5)(6) 8.5 ; Wavelength : (1)(2)(5) $520 \mathrm{~nm},(3)(4)(6) 585 \mathrm{~nm}$; $\bigcirc$ chloride, $\Delta \triangle$ sulfate ; Reference : water. (c) $[\mathrm{Be}(\mathrm{II})]$ : (1)(2)(5)(6) $4.44 \times 10^{-6} \mathrm{~mol} \mathrm{dm}^{-3}$, (3) (4) 0 ; [CAS] : $1.9 \times 10^{-4} \mathrm{~mol} \mathrm{dm}^{-3} ;$ [Zephiramine] : $5.9 \times 10^{-3}$ mol dm ${ }^{-3} ; \quad \mathrm{pH}: 10.2$; Wavelength : $520 \mathrm{~nm}$; Reference: (1) (4) water; (5)(6) difference in absorbance of (1) and (3), and (2) and (4), respectively; $\bigcirc$ chloride, $\Delta$ sulfate

と共に吸光度は増大する傾向を示すが，その増大率は $\mathrm{Cl}^{-}>\mathrm{SO}_{4}{ }^{2-}$ であった。 又, Fig. 5(b), Fig. 5(c)におい て, pH 3.5 での $520 \mathrm{~nm}$ における吸光度の増大は, 陰 イオン濃度の増大による $D_{\mathrm{H} 2 \mathrm{~L}}$ の増大に基づく $\left[\mathrm{H}_{2} \mathrm{~L}^{2-}\right]_{\mathrm{s}}$ の増大のためと考えられる。しかし， $\mathrm{pH} 3.5$ 及び 8.5 での吸収極大波長の一つである $585 \mathrm{~nm}, \mathrm{pH} 8.5$ 及び $\mathrm{pH} 10.2$ での $520 \mathrm{~nm}$ における吸光度の増大は, それぞ れ $\left[\mathrm{H}_{2} \mathrm{~L}^{2-}\right]_{\mathrm{s}}$ 及び $\left[\mathrm{HL}^{3-}\right]_{\mathrm{s}}$ の増大に基づくと考えられる ものより大きな吸光度を示した。これは，陰イオンとミ セル陽電荷の静電的作用によって, ミセル表面電位の増 $大^{2) 15)}$ や誘電率の低下により, CAS 分子内の電子遷移 に影響を与えたためと考えられる。

又, Fig. 5(c)に見られるように, ゼフィラミン存在 下のベリリウムの吸光光度定量において, 試料液と対照 液中の塩化物イオン及び硫酸イオンの濃度をほぼ等しく して吸光度を測定すると，これら陰イオンの影響を除く 
ことができた

\section{文献}

1) 西田 宏: 分析化学, 36, 547 (1987).

2) F. H. Quina, H. Ghaimovich : J. Phys. Chem., 83, 1844 (1979).

3) N. Funasaki : J. Phys. Chem., 83, 1998 (1979).

4) R. Rychlovský, I. Némcová : Talanta, 35, 211 (1988).

5) E. Pramauro, E. Polizzetti : Anal. Chim. Acta, 126, 253 ( 1981$)$

6）上野 実: “界面活性剂，物性，応用，化学生態 学”, 北原文雄, 玉井康勝, 早野茂夫, 原一郎 編, p. 80 (1980), (講談社).

7）早野和一：“界面活性剂ハンドブック”, 高橋越 民，難波義郎，小池基生，小林正雄編，p. 204 (1970), (工業図書).

8) 西田 宏: 分析化学, 31, 156 (1982).

9) E. Polizzetti, E. Pramuro:J. Phys. Chem., 88, 990 (1984).

10) C. Hirose, L. Sepūlveda : J. Phys. Chem., 85, 3689 (1981).

11) L. Sommer, V. Kubáń : Anal. Chim. Acta, 44, 333 (1969).

12) 西田 宏: 分析化学, 25, 866 (1976).

13）岡 好良: “実験化学講座, 続 7”, 日本化学会編, p. 203 (1968), (丸善).

14）中本一男: “金属キレート（II）”，上野景平，坂口 武一編, p. 29 (1969), (南江堂).

15) E. A. Lissi, E. B. Abuin, L. Sepúlveda, F. H. Quina : J. Phys. Chem., 88, 81 (1984).

16) H. V. Tartar : J. Phys. Chem., 59, 1195 (1955).

$$
\text { is }
$$

Effect of Zephiramine and chloride ion on acid dissociation constants of Chromazurol S. Hiroshi NisHidA (Faculty of Engineering, Iwate University, 4-3-5, Ueda, Morioka-shi, Iwate 020)

In the presence of Zephiramine (ZCl), the apparent third acid dissociation constant $\left(K_{\mathrm{a} 3}^{\prime}\right)$ of Chromazurol S (CAS, $\mathrm{H}_{4} \mathrm{~L}$ ) decreased with the increase of the chloride ion concentration and the Zephiramine concentration. Form this result, the partition ratios $\left(D_{\mathrm{H} 2 \mathrm{~L}}\right.$ and $\left.D_{\mathrm{HL}}\right)$ of CAS $\left(\mathrm{H}_{2} \mathrm{~L}^{2-}\right.$ and $\left.\mathrm{HL}^{3-}\right)$ between the water phase and the micellar pseudo phase were estimated. Very significant positive correlations between $D_{\mathrm{H} 2 \mathrm{~L}}$ and the square of the chloride ion concentration, and between $D_{\mathrm{HL}}$ and the chloride ion concentration were found. Therefore, $K_{\mathrm{a} 3}^{\prime}$ might be given by $K_{\mathrm{a} 3}^{\prime}=K_{\mathrm{a} 3} \times(1+$ $\left.k_{\mathrm{HL}}\left[\mathrm{Cl}^{-}\right] V_{\mathrm{s}}\right) /\left(1+k_{\mathrm{H} 2 \mathrm{~L}}\left[\mathrm{Cl}^{-}\right]^{2} V_{\mathrm{s}}\right)$, where $K_{\mathrm{a} 3}^{\prime}$ : the third acid dissociation constant of CAS in the absence of Zephiramine, $k_{\mathrm{H} 2 \mathrm{I}}^{\prime}=D_{\mathrm{H} 2 \mathrm{~L}} /\left[\mathrm{Cl}^{-}\right]^{2}$ and $k_{\mathrm{HL}}=D_{\mathrm{HL}} /\left[\mathrm{Cl}^{-}\right]$ (the constant in the respective chloride ion concentration), and $V_{\mathrm{s}}$ : the micellar volume fraction. This equation could not be explained by the ion-exchange reaction between CAS in the aqueous phase and the bound counter ion in the micellar phase. This equation indicated incorporation into the micelles of compounds made up of Zephiramine, CAS and chloride ion formed in the aqueous phase, being successfully by assuming the formation of $\mathrm{Z}_{2} \mathrm{H}_{2} \mathrm{~L}(\mathrm{ZCl})_{2}$ and $\mathrm{Z}_{3} \mathrm{HL}(\mathrm{ZCl})$ as compounds incorporated into the micelles. In the presence

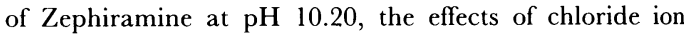
concentration on the beryllium-CAS 1:2 complex formation and the spectrophotometric determination of beryllium with CAS were also investigated. The complex incorporated in the micelles was considered as $\mathrm{Z}_{5} \mathrm{Be}$ $(\mathrm{OH})(\mathrm{HL})_{2}(\mathrm{ZCl})_{2}$. Beryllium was successfully determined by matching the chloride ion concentration between the sample and reference solution.

(Received November 28, 1988)

\section{Keyword phrases}

effect of chloride on acid dissociation of Chromazurol S in Zephiramine solution ; effect of chloride on partition ratio of Chromazurol S in Zephiramine solution; spectrophotometry of Be with Chromazurol S and Zephiramine; Be-Chromazurol $\mathrm{S}$ complex formation in Zephiramine solution. 